Earth Common Journal Regular Issue The Voice of Change

MacEwan University

Volume 3, Number 1, September 2013

\title{
One World, One Ocean, One Mission
}

\author{
Tracey L. Anderson* \\ MacEwan University, Canada
}

\begin{abstract}
MacGillivray Freeman Films was founded over forty years ago by Greg MacGillivray and the late Jim Freeman. In 2011, the company launched "the world's largest ocean media campaign, a 10-year global initiative called One World One Ocean" (MacGillivray Freeman Films, 2010, Our History, para. 10), an awareness and change campaign focusing on saving the world's oceans. The mission of One World One Ocean (OWOO) is to use "the power of film, television, new media and education initiatives... to change the way people see and value the ocean - and motivate action to restore it" (OWOO, 2012, Mission, para. 4). One World One Ocean's science advisors, including principal advisor Dr. Sylvia Earle, believe that "the ocean is at a tipping point... our actions over the next 10 years will determine the state of the ocean for the next 10,000 years" (OWOO, 2013, Why the Ocean?, para. $3)$. The media types used in the organization's campaign were chosen because MacGillivray Freeman Films wants to develop and expand on its film-industry successes. This article outlines the history of One World One Ocean and explores its mission, its history, its scientific basis, its current projects and initiatives, its successes to date, and its future goals. It explains why these media platforms were chosen to support the organization's mission and explores the vital questions of why it is important for all of us that we save the world's oceans and how this mammoth task can be tackled before it is too late. The purposes of this article are to inform readers about One World One Ocean and to inspire them to consider ways they can work to achieve the organization's crucial goals.
\end{abstract}




\section{Introduction}

MacGillivray Freeman Films was founded over forty years ago by Greg MacGillivray and the late Jim Freeman. The award-winning film production company creates "giant screen" IMAX films and shows them in theatres around the world. In 2011, MacGillivray Freeman Films launched "the world's largest ocean media campaign, a 10-year global initiative called One World One Ocean” (MacGillivray Freeman Films, 2010, Our History, para. 10), an awareness and change campaign that focuses on saving the world's oceans.

\section{Mission}

The main mission of One World One Ocean (OWOO) is to use "the power of film, television, new media and education initiatives... to change the way people see and value the ocean - and motivate action to restore it" (OWOO, 2012, Mission, para. 4). One World One Ocean's science advisors, including principal advisor Dr. Sylvia Earle, a renowned oceanographer, National Geographic explorer-in-residence, and former chief scientist of the National Oceanic and Atmospheric Administration (NOAA) in the United States, believe that "the ocean is at a tipping point.... our actions over the next 10 years will determine the state of the ocean for the next 10,000 years" (OWOO, 2013, Why the Ocean?, para. 3). Greg MacGillivray, co-founder of MacGillivray Freeman Films and chairman of the One World One Ocean Foundation (OWOOF), a public charity sharing the same goals as the campaign, describes the negative consequences of failing to act for the sake of our oceans. "If we don't shake people up now... we're not going to have the same magical oceans left in forty years" (OWOOF, 2013, Who We Are, para. 2).

\section{The Science}

Why did MacGillivray and Freeman choose to fight for the ocean? Because "the ocean is Earth's life support" (OWOO, 2013, Why the Ocean?, para. 1). It is the source of $97 \%$ of our water and 50 to $70 \%$ of our oxygen; it regulates the climate, absorbs carbon dioxide, and provides protein for more than a billion people (OWOO, 2013, Why the Ocean?, para. 1). Human beings are highly dependent on the ocean for our continuing existence; unfortunately, the ocean is in peril.

The problems facing the ocean are broad and varied. Populations of many large fish, such as tuna, halibut, and cod have been overfished and estimates are that " $90 \%$ of the big fish are gone [and] the average size of the remaining big fish has been cut in half or 
less in the last 50 years" (OWOO, 2013, Why the Ocean?, para. 2). In addition, the ocean has about 405 dead zones which are "areas where there is little to no oxygen due to fertilizer run-off and nitrogen pollution" (OWOO, 2013, Why the Ocean?, para. 2). Fortunately, these dead zones are reversible if their causes can be reduced or eliminated. For example, "efforts by countries along the Rhine River to reduce sewage and industrial emissions have reduced nitrogen levels in the North Sea's dead zone by upwards of 35 percent" (Scientific American, 2013, para. 4).

A third example of the peril the ocean faces relates to coral reefs. According to the Global Coral Reef Monitoring Network, estimates from 372 coral reef scientists and managers from 96 countries show that "the world has effectively lost $19 \%$ of the original area of coral reefs; $15 \%$ are seriously threatened with loss within the next 10-20 years; and $20 \%$ are under threat of loss in 20-40 years" (Wilkinson, 2008, p. 5). This problem, too, is reversible. World Resources Institute senior associate Lauretta Burke says, "Despite the dire situation for many reefs, there are reasons for hope. Reefs are resilient, and by reducing the local pressures on reefs [fishing, coastal development and pollution], we can help buy time to find solutions to global threats that can preserve reefs for future generations" (as cited in NOAA Coral Reef Conservation Program, 2011, New Analysis, para. 4).

A major issue related to many of the individual problems is that oceans cover $71 \%$ of the Earth's surface, but less than $2 \%$ of oceans are protected in comparison with $12 \%$ of land that is protected (OWOO, 2013, Why the Ocean?, para. 2). If we don't work to save the ocean, and we keep on the path we are on, "many popular seafood species will likely be wiped out within 40 years [and] we're within a century — possibly even less of a world where jellyfish are the only wild seafood option left" (OWOO, 2013, Why the Ocean?, para. 3). With these concerns in mind, One World One Ocean is tackling the problems through education and multi-media.

\section{Media Choices}

Many organizations advocate for the ocean such as The Blue Ocean Institute, the Deep Sea Conservation Coalition and the Institute for Ocean Conservation Science (Marine Bio, n.d., Global Marine Conservation). One major difference about One World One Ocean is its focus on media to achieve its goals. Greg MacGillivray explains, "What makes our campaign unique from other ocean campaigns is our focus on using motion picture entertainment and compelling storytelling to drive major social change on behalf of the oceans" (OWOO, 2011). 
The media types used in the One World One Ocean campaign were chosen in part because MacGillivray Freeman Films wants to develop and expand on its film-industry successes. "We will build our constituency by starting with the fan base we've built over the past 35 years with 36 giant-screen films at 250 IMAX theatres in 32 countries where we are the only documentary film company to have generated $\$ 1$ billion in worldwide ticket sales" (MacGillivray Freeman Films, 2010, One World One Ocean Campaign, para. 2). Image Maximum, also called IMAX, is "a motion picture format with the capacity for greater size and clearer resolution than standard movie systems" (TechFAQ, 2012). Other current and future OWOO media projects include a theatrical documentary, several television series, online videos and three new ocean-themed IMAX films in 3D (OWOO, 2012, Press Release).

Image-based media such as documentary films have long been known to be effective tools of change. One major reason for this relates to language and literacy barriers, which films and other images remove (Video Volunteers, n.d., The Power of Media, para. 2). Someone who can't read or who doesn't speak English can still learn many things from visual imagery and be compelled to action. Bill Gentile, an independent journalist and American University professor explains why imagery is so effective. "You've got the images, which are the driving force; you've got natural sound... and you've [often] got narration" (as cited in US Dept. of State, 2013, How to Say It, para. 3). Liba Rubenstein, director of outreach for causes and politics for Tumblr adds, "Media is a profoundly powerful tool for connecting with people and guiding them up the ladder of engagement" (as cited in US Dept. of State, 2013, How to Spread It, para. 2). Shaun MacGillivray, Producer and Managing Director at MacGillivray Freeman Films, discusses the emotional value of media images to the OWOO campaign, "the goal... is to connect people emotionally to the ocean, so they feel a desire to protect it" (as cited in OWOO, 2011).

If a single picture is worth 1000 words, then the 1000 images in a film are worth at least a million words. MacGillivray Freeman Films' own research shows that the films are making an impact. One example comes from telephone interviews conducted with viewers of Journey Into Amazing Caves one week after they saw the film (2010, Educational Impact, para. 4):

- $\quad 93 \%$ discussed the film with someone on the day they saw it,

- $50 \%$ discussed it within the following week,

- $57 \%$ recommended it to others and

- $40 \%$ said it affected their thoughts within the week. 
The programs and initiatives of One World One Ocean focus substantially on films as tools for social change; however, the organization also strives to "extend the intellectual and social impact of our films [by designing] educational outreach programs that broaden the film-going experience [to] carry forward the themes and issues presented in each film" (MacGillivray Freeman Films, 2010, Our Mission, para. 2). These programs aim to reach as wide an audience as possible and to deepen and expand the message presented by the films. Some of these resources include teacher's guides, family activity guides, a speaker series, traveling exhibits and companion books (MacGillivray Freeman Films, 2010, An Education Legacy).

\section{Projects and Initiatives}

In its mission to save the ocean, One World One Ocean has undertaken diverse projects and initiatives. One highly successful initiative is Surviving in a Changing Arctic, which produced the visually stunning IMAX film To the Arctic and its companion book with photographs by Florian Schulz, an award-winning nature photographer (OWOO, 2013, To the Arctic.). The film follows one year in the life of arctic wildlife including caribou, walruses and polar bears to highlight the consequences that climate change is rapidly bringing to this region that is warming twice as quickly as anywhere else (G. MacGillivray, as cited in Loose, 2012, How Is It Changing). At first glance, it may not be obvious what the Arctic region has to do with risks to the ocean. A clear connection does exist, however. The problem is complex, but One World One Ocean summarizes it this way: "As glaciers melt, fresh water enters the ocean, making the cold, deep water warmer, less salty and less able to hold oxygen and carbon dioxide. As the current is altered, it will have unknown effects on everything from sea life to our climate" (2013, Why the Arctic?, Ocean Engine).

To the Arctic's success can be measured in several ways. First, its box office receipts surpassed \$11 million in November 2012 (Ocean Minds, 2012, para. 1). Second, the film has received the recognition of others in the documentary industry, including the Giant Screen Cinema Association, which awarded the film two top honours in 2012: Best Film Short Subject and Best Film for Lifelong Learning (Ocean Minds, 2012, para. 2). Third, and most important, the film has motivated viewers to action. In an independent survey, respondents noted the following after seeing the film (Reckas, 2012, para. 5-7):

- $60 \%$ accessed websites, literature or other resources to learn more about changes in the Arctic, 
- $86 \%$ believed seeing To The Arctic will impact the way they vote on environmental issues in the future and

- $88 \%$ indicated that they have been, or plan to be, more environmentally sensitive with everyday decisions.

\section{Goals}

While One World One Ocean has had many successes to date and is proud of its accomplishments, the organization understands that saving the world's oceans is an ongoing process. "We don't think one film alone will change public perception of the ocean. We are committed to a long-term release of films and multi-media programming that will build awareness, and continue reminding people that a healthy ocean is essential to us all" (OWOO, 2013, Why We're Different, para. 2). Given that essentiality, what are One World One Ocean's specific goals to save the ocean?

The organization has three main goals. The first is to encourage consumers to buy sustainable seafood products (OWOO, 2013, Goals, \#1). Many of the problems the ocean faces are the result of overfishing and species collapse, where a species "has fallen to 10 per cent of its highest known numbers" (Layton, 2013, para. 2). If we want to preserve fish populations for future generations, a sustainable seafood industry is critical. It is not necessary to stop eating fish and seafood; instead, "we can create a true shift to sustainable seafood.... [if we] make the right choices at the grocery store and at restaurants" (OWOO, 2013, Goals, \#1).

One World One Ocean believes this goal is achievable through awareness raising and helping people understand the environmental implications of what they choose to eat. A major OWOO initiative to meet this goal is its GO Fish! Making Seafood Month Sustainable campaign, which encourages seafood consumers to take "simple actions.... to celebrate seafood in a way that's healthy for the ocean" (OWOO, 2013, Go Fish!, para. 1). One tool the organization uses is the Know Your Seafood infographic (OWOO, 2013, Goals, \#1) which includes a red list and a green list of types of fish and seafood to buy and suggested retailers that sell sustainable seafood.

The second goal is to reduce plastic pollution (OWOO, 2013, Goals, \#2). Plastics are as big a problem in the ocean as they are on land, perhaps even more so. According to the Algalita Marine Research Foundation, plastic in the ocean causes many negative effects: 
Fish and seabirds mistake plastic for food. Plastic debris release chemical additives and plasticizers into the ocean. Plastic also adsorbs hydrophobic pollutants, like PCBs, and pesticides like DDT. These pollutants bioaccumulate in the tissues of marine organisms, biomagnify up the food chain, and find their way into the foods we eat. (n.d., p. 2)

In addition, sea animals can get tangled in the debris and end up injured or dying of strangulation. For all these reasons, we must reduce the plastic pollution that gets into the ocean. While this goal is challenging, it is not impossible. Individuals can make more environmentally responsible decisions about the amount of packaging on items they purchase and about how they carry and transport personal items. As an organization, One World One Ocean helps meet this goal by providing "tools for people to use in their community to create public awareness of plastic waste" (OWOO, 2013, Goals, \#2), such as the infographic Plastic Breakdown which includes information on how plastics harm the ocean, how much plastic is in the ocean and how we can help reduce new plastic pollution in the future.

One World One Ocean's third goal is to expand protected areas to $10 \%$ of our oceans from the currently less than 2\% (OWOO, 2013, Goals, \#3). "Protected" refers to legal protections put in place for a specified area of the ocean that "regulates what can be done there in terms of fishing, boating, and other forms of access" (OWOO, 2013, Goals, \#3). This protection can take the form of national marine sanctuaries, marine protected areas, or world heritage marine sites depending on the location and the degree of protection granted (OWOO, 2013, Goals, \#3). Studies show "rebounds in species diversity and population levels within five to ten years after gaining protections, actually boosting things like fishing and ecotourism"(OWOO, 2013, Goals, \#3). Strides towards meeting this goal have already taken place. For example, the Convention on Biological Diversity, signed in 2012 by 193 countries, passed a declaration that "10 per cent of coastal and marine areas [will be] conserved through effectively and equitably managed, ecologically representative and well-connected systems of protected areas" by 2020 (Target 11).

\section{What We Can Do}

One World One Ocean's goals are grand, hopeful goals that cover a lot of water, but they are realistic, and we can help the organization meet those goals. We can buy sustainable seafood from responsible retailers. We can reduce the plastics we purchase and recycle those that we do use so that they do not end up in the ocean. We can 
encourage governments and other organizations to work toward increasing the areas of the ocean that are protected and vote for officials who care about the environment as much as we do. We can spread the word to friends and family about the issues facing the ocean and explain why they should follow suit and undertake these same actions. One World One Ocean is a leader in the area of ocean conservation, but for their work to succeed we must follow.

\section{Conclusion}

Through its initiatives, One World One Ocean is a strong voice for change in the ways that humans interact with the ocean. The organization has demonstrated what needs to be done to protect the world's major water source and provided ideas about how we can do it. To date, the organization has inspired audiences and led the way when it comes to protecting the ocean. It has begun successful media-driven programs based on a central idea: "A critical part of our approach will be showcasing stories of hope and success.... We want to show the world that we can do this. We can save the ocean" (S. MacGillivary, as cited in OWOO, 2011). And indeed we must save it because "everyone, everywhere depends on a healthy sea" (OWOO, 2013, Why the Ocean?, para. 1).

* Author: Tracey L. Anderson tanght English as a second language in China, Macedonia, Morocco, and the United Arab Emirates. She has a Bachelor of Applied Communications in Professional Writing degree from MacEwan University in Edmonton, Canada. She is a freelance editor and writer. When she's not working with words, Tracey enjoys travel, reading, movies, and fine dining.

\section{References}

Algalita Marine Research Foundation. (n.d.). Plastic debris from rivers to sea. Retrieved from http://www.algalita.org/pdf/PLASTIC\%20DEBRIS\%20ENGLISH.pdf

Convention on Biological Diversity. (n.d.). Target 11 - Technical rationale extended. Retrieved from http://www.cbd.int/sp/targets/rationale/target-11/

IMAX. (n.d.) IMAX: To the Arctic. Retrieved from http://www.imax.com/tothearctic/site.html\# 
Layton, Julie. (2013). Endangered species: Why would there be no more fish in 40 years? Animal Discovery. Retrieved from http://animal.discovery.com/endangeredspecies/no-more-fish.htm

Loose, T. (2012, April 25). Interview with Greg and Shaun MacGillivray. Coast Magazine. Retrieved from http://www.coastmagazine.com/articles/macgillivray-2153--.html

MacGillivray Freeman Films. (2010). An education legacy. Retrieved from http://www.macgillivrayfreemanfilms.com/site/our-educational-outreach/aneducation-legacy.html

MacGillivray Freeman Films. (2010). Educational impact. Retrieved from http://www.macgillivrayfreemanfilms.com/site/our-educationaloutreach/educational-impact.html

MacGillivray Freeman Films. (2010). One World One Ocean campaign. Retrieved from http://www.macgillivrayfreemanfilms.com/site/our-company/companyprofile/one-world-one-ocean-campaign.html

MacGillivray Freeman Films. (2010). Our history. Retrieved from http://www.macgillivrayfreemanfilms.com/site/our-company/companyprofile/our-history.html

MacGillivray Freeman Films. (2010). Our mission. Retrieved from http://www.macgillivrayfreemanfilms.com/site/our-company/companyprofile/our-mission.html

Marine Bio. (n.d.). Marine conservation organizations. Retrieved from http://marinebio.org/oceans/conservation/organizations.asp

National Oceanic and Atmospheric Administration. (2011, May 16). New analysis: 75\% of coral reefs under threat. Retrieved from http://coralreef.noaa.gov/aboutcrcp/news/featuredstories/feb11/cu threat/

Ocean Minds. (2012, November 26). 3D film To The Arctic passes $\$ 10$ million milestone worldwide. Retrieved from http://www.oceanminds.com/3d-film-to-the-arcticpasses-10-million-milestone-worldwide/

One World One Ocean. (2011, October 12). MacGillivray Freeman Films director launches One World One Ocean campaign [Press Release]. Retrieved from http://www.oneworldoneocean.com/press releases/entry/macgillivray-freemanfilms-director-launches-one-world-one-ocean-campaign\#.UYHMc7WsiSo 
One World One Ocean. (2012). Mission. Retrieved from http://www.oneworldoneocean.com/

One World One Ocean. (Oct. 5, 2012). MacGillivray Freeman's One World One Ocean campaign voted Best Digital Interactive Campaign at the 2012 Blue Ocean Film Festival [Press Release]. Retrieved from http://www.oneworldoneocean.com/media/press/OWOO Wins Best Campaign at BLUE $10 \quad 05$ 12.pdf

One World One Ocean. (2013). Goals. Retrieved from http://www.oneworldoneocean.com/pages/our-goals\#.UX19DLWsiSo

One World One Ocean. (2013). Go fish! Retrieved from http://www.oneworldoneocean.com/initiatives/gofish

One World One Ocean. (2013). To the Arctic. Retrieved from http://www.oneworldoneocean.com/content/to the arctic

One World One Ocean. (2013). Why the Arctic? Retrieved from http://www.oneworldoneocean.com/content/why the arctic

One World One Ocean. (2013). Why the ocean? Retrieved from http://www.oneworldoneocean.com/pages/why-the-ocean\#.UX1szLWsiSo

One World One Ocean. (2013). Why we're different. Retrieved from http://www.oneworldoneocean.com/pages/why-were-different\#.UX18t7WsiSo

One World One Ocean Foundation. (2013). Who we are. Retrieved from http://www.oneworldoneoceanfoundation.org/about-us/who-we-are.html

Reckas, T. (2012, May 9). To The Arctic moves the needle [Web blog post]. Retrieved from http://www.oneworldoneocean.com/blog/entry/to-the-arctic-moves-theneedle\#.UYHUObWsiSo

Scientific American (2013). What causes ocean dead qones? Retrieved from http://www.scientificamerican.com/article.cfm?id=ocean-dead-zones

Tech-FAQ. (2012). IMAX. Retrieved from http://www.tech-faq.com/imax.html

United States Department of State. (2013, Feb. 20). More than words: Using video to inspire change. Retrieved from http://iipdigital.usembassy.gov/st/english/pamphlet/2013/02/20130212142452.ht ml\#axzz2R7zYaTVX

Video Volunteers. (n.d.). Video and social change. Retrieved from http://www.videovolunteers.org/impact/video-and-social-change/ 
Wilkinson, C. (2008). Executive summary. In Global Coral Reef Monitoring Network, Status of coral reefs of the world: 2008 (pp. 5-19). Retrieved from

http:/ / www.reefbase.org/download/gcrmn download.aspx?type $=10 \&$ docid $=1331$ $\underline{2}$ 